\title{
Inclusive Education for Children with Specific Learning Difficulties: Analysis of Opportunities and Barriers in Inclusive Education in Slovenia
}

Marija KavkleR ${ }^{\star 1}$, Milena Košak BabudeR ${ }^{2}$ And Lidija Magajna ${ }^{3}$

$\approx$ Inclusive education allows for universal inclusion, participation and achievement of all children, including children with specific learning difficulties (SpLD). Children with SpLD form a heterogeneous group with diverse cognitive deficits, special educational needs (SEN) and strengths, and have a legislated right to the continuum of both assistance and support programmes. Although their intellectual capacity is average or above average, their learning achievements in some learning domains are modest, and they are poorly integrated into their social environment, which often results in their discrimination. Barriers and opportunities in the area of SpLD were analysed with the aid of Ball's model (1994), with factors and conditions being analysed within the contexts of policy influence, text production and practice. The contexts of policy influence and text production provide the basic conditions for the inclusive education of children with SpLD. The context of influence on inclusive policy for children with SpLD represents a systematic approach to policy initiation and to the prerequisites for its implementation in practice. The context of policy text production focuses on professionals and their impact on the enactment of the rights of children with severe SpLD. The context of practice concerns barriers and opportunities for implementing inclusion in practice. Early identification and diagnosis of pupils' strengths, deficits and SEN, together with intensified treatment corresponding to the SEN of children with SpLD, could significantly influence the efficiency of the educational process. Barriers, primarily of an immaterial nature, are mainly encountered in those schools that do not implement the five-tier Response to Intervention (RTI) approach. This approach enables children with SpLD a continuum of team-based diagnostic evaluation, effective adaptations and assistance. The main reasons for the unfavourable situation concern education professionals

$1 \quad$ * Corresponding Author. University of Ljubljana, Faculty of Education, Slovenia; marija.kavkler@guest.arnes.si

2 University of Ljubljana, Faculty of Education, Slovenia

3 University of Ljubljana, Faculty of Education, Slovenia 
and their attitude towards children with SpLD, poor knowledge of SpLD, a lack of teamwork in problem solving, and a lack of partnership commitment between education professionals, parents and children. It is expected that changes could be brought about through innovations in the education of future teachers, and through positive cases of children with SpLD being treated effectively in practice. The conditions for the development of the inclusive treatment of children with SpLD could be created through legislative and systematic work.

Keywords: children with specific learning difficulties, inclusion, the context of policy influence, the context of policy text production, the context of practice, barriers 


\section{Inkluzivno izobraževanje otrok s specifičnimi učnimi težavami: analiza priložnosti in ovir inkluzije v Sloveniji}

Marija Kavkler ${ }^{*}$, Milena Košak Babuder in Lidija Magajna

$\propto$ Inkluzivna vzgoja in izobraževanje omogočata vključenost, participacijo in uspešnost vseh otrok, tudi tistih s specifičnimi učnimi težavami. Otroci s tovrstnimi težavami so raznolika skupina otrok z raznolikimi primanjkljaji, s posebnimi potrebami ter $z$ močnimi področji in uzakonjeno pravico do kontinuuma programov pomoči in podpore. So pogosto diskriminirani, saj kljub povprečnim in nadpovprečnim intelektualnim sposobnostim dosegajo nizke izobraževalne dosežke in so tudi socialno slabše vključeni. Analiza možnosti in ovir na področju specifičnih učnih težav je bila izvedena s pomočjo Ballovega modela (1994). V prispevku so analizirani dejavniki in pogoji v kontekstu vpliva na inkluzivno politiko, kontekstu oblikovanja zakonodaje in v kontekstu prakse. Kontekst vpliva politike in kontekst oblikovanja zakonodaje omogočata osnovne pogoje za inkluzivno vzgojo in izobraževanje otrok s specifičnimi učnimi težavami. V kontekstu vpliva na inkluzivno politiko za otroke s specifičnimi učnimi težavami je predstavljen sistematičen pristop k oblikovanju politike in razvoju pogojev za njeno uresničevanje v praksi. V kontekstu oblikovanja zakonodaje pa je predstavljen vpliv strokovne javnosti na uzakonitev pravic otrok s težjimi specifičnimi učnimi težavami. Ovire in možnosti za uresničevanje inkluzije v praksi so prikazane v kontekstu prakse. Zgodnje odkrivanje in diagnosticiranje močnih področij, primanjkljajev in posebnih potreb ter povečevanje intenzivnosti obravnave skladno s posebnimi potrebami otrok s specifičnimi učnimi težavami bi pomembno vplivali na učinkovitost vzgojnoizobraževalnega procesa. Ovire, ki primarno niso materialne narave, so prisotne v tistih šolah, ki ne uresničujejo petstopenjskega modela odziva na obravnavo, ki omogoča otrokom s specifičnimi učnimi težavami kontinuum diagnostičnega ocenjevanja, učinkovitih prilagoditev in oblik pomoči s pomočjo timskega soustvarjanja rešitev. Pomembni vzroki za neugodno stanje so: stališča strokovnih delavcev do posebnih potreb otrok, skromno znanje s področja specifičnih učnih težav ter premalo timskega reševanja izzivov in partnerskega odnosa med strokovnimi delavci, starši in otroki. Spremembe lahko pričakujemo od novosti pri 
izobraževanju prihodnjih učiteljev in pozitivnih primerov učinkovite obravnave otrok s specifičnimi učnimi težavami v praksi. S sistemskim in sistematičnim delovanjem bi lahko dosegli pogoje za razvoj inkluzivne obravnave otrok s specifičnimi učnimi težavami.

Ključne besede: otroci s specifičnimi učnimi težavami, inkluzija, kontekst vpliva na inkluzivno politiko, kontekst oblikovanja zakonodaje, kontekst prakse, ovire 


\section{Introduction}

The UN Convention on the Rights of the Child (1989, in KOP, 1990) is one of the central documents delineating the rights of all children, including children with SEN. In all social, economic and cultural contexts and policies, children with SEN, as well as children with SpLD, tend to be discriminated against and marginalised too a much greater extent than their peers without SEN. There is too much emphasis on the deficits, disabilities and barriers of children with SEN, while their strengths remain undervalued and their SEN neglected. Although some positive changes have occurred in recent years, there is still a big gap between the needs of children with SEN and the way these needs are addressed in school and society (UNICEF, 2007).

The inclusive treatment of children with SEN (and with SpLD) depends greatly on the model selected: the medical model or the social model. The medical model emphasises the deficits, impairment, disabilities and barriers of an individual, which is why medical-rehabilitative treatment in specialised institutions is, in this model, presented as the most effective way of improving the individual's achievements (Oliver, 2004; Hargrass, 2005). In the social model, attention is shifted from the "personal tragedy" to the need for changing the social environment in which children with SEN live and act (UNESCO, 2001). Inclusion is based on the social model, which is why the social and educational environment should be adapted for children with SEN as much as possible. The social model of including children with SEN has been the focus in the EU since as early as 1991 (Ainscow, 2005). One of the most important factors contributing to inclusive schooling of children with SEN in EU countries is the shift from a medical orientation to a more socially interactive orientation (Meijer, Soriano, \& Watkins, 2003; Kavkler, 2011).

Inclusion and the quality of education are interrelated, as the ethics of inclusion contributes considerably to the quality education of all children. Both influence the development of a society that is just and democratic, and that values diversity (European Agency for Development in Special Needs Education, 2009). There can be no quick changes in the schooling of children with SEN (Falvey \& Givner, 2005). Inclusion is not just another programme or an adapted strategy, it is a way of living together so that everyone gains something, is valued and feels connected with the community. Inclusion should not be equated with integration, nor should it be understood as a mere supplement to the existing school structure; instead, it should be seen as a process of changing society, the environment and institutions, which need to consider and value diversity more (Hegarty, 2003; European Agency for Development in Special Education, 2010). 
Child-centred school is a basis for a human-centred society that respects diversity, allows for the optimal development of every individual and their potential, and treats all people with respect (Lorenz, 1999). In the long term, inclusive education eliminates prejudices towards children with SEN amongst their peers (Drabble, 2013). School teams that have opted for inclusion deal constructively with the barriers that all children encounter in the educational process, barriers that children with SEN face to an even greater extent.

\section{Definition and Classification of Children with Low Educational Achievement}

Children with low educational achievement may experience a diverse range of problems, which are often complex and difficult to resolve.

According to Lerner's (2003) definition, children and youth with low achievement (referred to in the continuation merely as children) are a very diverse group of children with various cognitive, social, emotional and other features, who have significantly greater difficulties in learning than the majority of their peers. Some experience only general learning difficulties (LD), some face only SpLD, while many experience both.

In Slovenia, children with low achievement or learning problems (without intellectual disabilities) account for $20 \%$ of all school children, and are classified into general learning difficulties (general LD) and specific learning difficulties (SpLD). The term specific learning difficulties (SpLD) implies a neurobiological nature of the learning impediment in specific learning areas, and includes developmental dyslexia, dyscalculia and nonverbal learning disabilities. Alternative terms in use for SpLD are learning disabilities, specific learning disorder (DSM V in APA, 2013) or specific developmental disorders of scholastic skills (ICD 10, 1996).

Children with SpLD (the entire continuum ranging from mild to severe SpLD) are a very diverse group. Due to known or unknown disabilities or differences in the functioning of their central nervous system, they experience severe difficulties in reading, writing, spelling and arithmetic, despite their average or above-average intellectual abilities. Delays and deficits in attention, memory, thinking, coordination, communication, social skills and emotional maturity are also present. These deficits influence the cognitive processing of verbal and non-verbal information, hinder the acquisition and automation of learning skills, and influence learning and behaviour throughout the individual's lifetime. They are internal and not primarily related to either inappropriate teaching and other environmental factors, nor are they related to impairment of 
a visual, hearing or motoric kind, mental disabilities or behavioural and emotional problems (disorders), although they may occur simultaneously with such problems (Kavkler \& Magajna, 2008).

SpLD are characterised by the child's strengths and specific disabilities or deficits, causing significantly lower learning achievement in some learning areas (reading, writing, arithmetic and spelling) than would be expected given the child's age, class, social and cultural background, and level of intellectual ability. Such disabilities can occur with gifted children as well, and can be very persistent in spite of hard work and regular training. They hinder learning in specific areas, both in the case of children with socially and culturally disadvantageous backgrounds and of children with adequate support and understanding in their families.

When identified in time and offered suitable forms of teaching and assistance, many children with SpLD can compensate for their problems by using effective learning techniques and activating their strong learning areas, even to the extent that they are successful and need no further guidance and additional professional assistance.

\section{Historical Perspective}

A review of past professional endeavours can help us understand the development of the field of general LD and SpLD (Magajna, Kavkler, \& Križaj Ortar, 2003). In 1976/77, the share of primary school pupils enrolled in special institutions was as high as $3.4 \%$. Many of these children did not actually have intellectual disabilities, but rather experienced severe general LD and SpLD; they were nonetheless enrolled in schools that implemented programmes with lower educational standards. There was a high dropout rate in primary schools between 1960 and 1980, with only 90\% of children completing primary school successfully, prompting responsible education professionals to attempt to address the situation. In order to reduce the dropout rate in primary schools, various preventive measures were introduced in preschool and medical institutions after 1980, e.g., psychological screening of all 3-year-olds and speech-language examinations for 5-year-olds. In addition, 6-year-olds were included in preschool programmes (50o hours) in which they developed the knowledge and skills necessary for the more successful formal education of risk groups. School counselling services were expanded. The reading skills of all 8-year-olds were checked preventively, and assistance was offered wherever needed (Magajna et al., 2003). In Slovenia, a comprehensive and systematic approach helped to significantly reduce the dropout rate. 


\section{Analysis of Opportunities and Barriers in Inclusive Edu- cation for Children with Specific Learning Difficulties}

At the Standing Conference of European Ministers of Education of the Council of Europe in 2010, Zgaga (Žolnir, 2010) emphasised a major new challenge facing education professionals: to acknowledge the diversity in the population of children who do not learn with the same eagerness, nor with the same ability and success in all subjects. The diversity of the school population is evident from their learning achievements. In Slovenia, $1.3 \%$ of pupils failed to complete primary school in 2010/11 (SURS, 2012). On average, the results of international research were good. PISA results (2012, in Štraus, Šterman Ivančič, \& Štigl, 2013), on the other hand, show that approximately $20 \%$ of 15 -year-olds, many of whom have general LD and SpLD, failed to reach Step 2 in various fields of literacy that would enable their learning achievement (Srebotnik, 2013). Children with SEN, almost $40 \%$ of whom are identified as having severe SpLD, have lower learning achievement in comparison to their peers in national testing as well, despite adjustments being made during testing. The National Centre for External Evaluation (RIC, 2013) found that, on average, children with SEN achieved 38.3\% points compared to their peers without SEN who achieve $53 \%$ points. Some $76.7 \%$ of children with SEN achieve $50 \%$ points and less compared to $40.2 \%$ of their peers with such a result (RIC, 2013). M. Peček Čuk and I. Lesar (2010) examined the differences that primary school teachers (207 class teachers and 207 subject teachers) perceive in the behavioural responses and learning achievement of children with SEN and those of their peers. Overall, the average learning achievement of children with SEN was significantly lower (average grade of 2.70) than that of their peers (average grade of 3.98). Children with severe SpLD have the lowest average learning achievement, at 2.05. Teachers also noted that children with severe SpLD stood out due to their negative self-image.

Children with mild, modest or severe SpLD, amounting to $10 \%$ of all children, constitute one of the most numerous groups of children with SEN, which is why the authors of the present article decided to analyse some factors influencing their educational achievement.

Barriers and opportunities for realising inclusive education of children with SpLD were analysed with the help of Ball's model (Ball, 1994; Tikondwe Kamchedzera, 2011; Kavkler, 2011). This model served as an analytical and conceptual framework for exploring the relation between the contexts of policy, legislation and practice in the area of inclusion. The educational and social needs of children with SpLD differ significantly from those of their peers due to 
deficits that are neuro-physiological in origin and impair learning. The article focuses mainly on the analysis of barriers and opportunities for the development of inclusion in the area of SpLD. Ball's model includes three interactive contexts: the context of policy influence, the context of policy text production and the context of practice.

\section{The Context of Policy Influence}

The context of policy influence is the context of policy-making in the field of the inclusion of children with SEN, including children with SpLD. Within this context, the formation of an inclusive policy is influenced by participants in power structures, ranging from the government, the relevant minister and representatives of departments of the Ministry of Education, Science and Sports, and the National Education Institute of the Republic of Slovenia, to key professional associations and individuals. It is they who have an impact on the choice of the theoretical frameworks used to define special needs, on delineating the population of children with SEN, on selecting either the medical or the social model, and on the social purpose and aims of children with SEN education. Education reforms, especially in the field of SEN, often create an ideological battlefield driven by various economic and other factors, as well as by the perceptions of the participants in power (Levine et al., 2003, in Tikondwe Kamchedzera, 2011; Ainscow, 2003).

Even some influential Slovenian experts in the field of education have a poor knowledge of the complexity and neurobiological background of learning deficits, and of the SEN of the child population with SpLD (the entire continuum ranging from mild to severe $\mathrm{SpLD}$ is referred to as SpLD, except in legislative and other definitions, which recognise severe SpLD), tending to deal with learning deficits as transitional, related only to early education. There is a fear that additional methods of professional assistance for the largest group of children with SpLD within the SEN category would require overabundant funding, as severe SpLD accounts for nearly $40 \%$ of all children identified with SEN. Those who doubt the complexity of SpLD and the right of children with SpLD to adaptations in their education process, as well as to additional professional assistance, fail to recognise that the financial resources used to finance professional assistance are the most economical investment a state or individual can make, as the adequate treatment of children with SpLD alleviates their educational, employment and social inclusion problems. The financial investment in education later delivers high returns that far exceed the cost of material and scientific resources (Bassanini \& Scarpetta, 2001; Jereb, 2011). 
The development of the field of SpLD has been based on analyses of practice, examination of foreign models and strategies, and systematic drafting of the required documents to implement changes in practice. In the continuation, some steps will be described that have influenced policy-making and the development of the field of SpLD. Some of the activities that have had a vital impact on the development of the field of SpLD have been implemented as part of the broader realm of low achievement.

The first time the criteria for identifying severe SpLD, the differences between varying degrees of SpLD from mild to moderate or severe SpLD, and the continuum of programmes for children with SpLD (Magajna \& Kavkler, 2002) were presented to a professional audience was in 2002. The population of children with severe SpLD was defined in detail in the Rules on Criteria for Determining the Type and Degree of Disadvantages, Impairments and Disabilities of Children with Special Needs (Magajna \& Kavkler, 2002). Nevertheless, the numerous challenges that still remain in defining and improving the criteria for assessing the severity of SpLD in the continuum of the child population with SpLD led to amendments, adopted in 2014, in the Criteria for Determining the Type and Degree of Disadvantages, Impairments and Disabilities of Children with Special Needs - Children with Deficits in Individual Learning Areas (Magajna et al., 2014).

The planned changes in the broader field of low achievement, which include both general LD and SpLD, were based on an analysis of the actual conditions. As part of the project Pupils with Learning Difficulties in Primary School - Developing a Comprehensive System of Effective Assistance (Magajna et al., 2005), a study was conducted to analyse the situation in the field of general LD and SpLD. It revealed that treatment of these pupils in Slovenia was not comprehensive, integrated and long term. There was a wide gap between the rapid progress of theory and scientific findings in various disciplines that deal with the different causes of LD, examine effective new approaches to study support and teaching strategies, and work on early identification and prevention, and the implementation of these findings in practice. The study exposed organisational and motivation problems as the most common and critical issues, along with problems related to the competence of teachers to assist children with general LD and SpLD. It was determined that education professionals differ significantly in their perception of $\mathrm{LD}$, as well as with regard to certain other key issues (ways of handling various types of LD). The study showed a clear distinction in assessing the effectiveness of various forms and sources of assistance between children and parents, on the one hand, and education professionals, on the other, while also highlighting challenges in communication and the lack 
of teachers' competence to recognise and acknowledge pupils' strengths.

The analysis of the problems in the field of general LD and SpLD, together with certain more recent models and concepts, an in-depth insight into good practice experiences and strengths, critical issues and barriers found in practice in Slovenia, and Slovenian and foreign documents, established the groundwork for a range of experts in various disciplines from faculties of the University of Ljubljana, the Counselling Centre, and the Education Development Office of the Republic of Slovenia, as well as experts from practice, to design a comprehensive and systematic support model entitled "The Concept of Working with Pupils with Learning Difficulties" (Magajna et al., 2008a). The document introduces a vision and practical suggestions for overcoming underachievement in education and working with children with general LD and SpLD - but not those with severe SpLD - ranging from identification, assessment, teaching and more specialised forms of assistance, to the team-based creation of solutions that allow for sufficient flexibility and adaptation to the various forms and contexts of difficulties. The emphasis is on a shift from certain traditional perceptions and approaches that insisted on focusing on difficulties and deficits, to the strengths perspective: identification and utilisation of the individual's strengths, and encouraging personal characteristics that can lead to a successful life and career even when some LD remain.

A conceptual framework for the systemic comprehensive treatment of children with general LD and SpLD, including severe SpLD to a certain degree, was developed to address the key problems of identification and treatment (The Concept 'Learning Difficulties in Primary School', Magajna et al., 2008a). As part of the concept, a five-step model of assistance was devised, based on scientific and material resources already available in the Slovenian school system. The five-tier RTI approach enables children at risk of school failure to be identified early and provided with effective study assistance and support in collaboration with all participants, from the children themselves to their parents and education professionals. As general and specific LD vary in their degree of intensity, there need to be various forms of assistance for children with SpLD, with increasing intensity and specificity on the spectrum from step 1 to step 5 in order to meet children's individual needs. Teaching organised this way and various forms of assistance require increasingly specific knowledge on the part of the education professionals who provide the assistance. The entire spectrum of the five steps of assistance is only effective if education professionals, parents and pupils work together well and deliver on their responsibilities, which, in turn, requires evaluation. By including specific targets and agreed responsibilities, an "individual working project of help", implemented in schools in steps 
1-4, helps to provide an overview of the work with a child with SpLD. After each step, a final evaluation assessment must to be made, which includes an assessment of both the child's progress and the effectiveness of the assistance, as well as opinions on and proposals for its continuation. In step 5, a team of the school's education professionals makes an individualised programme for the child with severe SpLD, which serves as a binding document for teachers and other education professionals.

The Guide to Customized Primary School Curriculum Implementation with Additional Professional Assistance - Children with Deficits in Individual Learning Areas (Kavkler et al., 2008) features a varied range of adaptations to overcome various deficits of children with severe SpLD.

In the period from 2009 to 2011, as part of the EU project Professional Basis for Further Development and Implementation of the Concept 'Learning Difficulties in Primary School', a project group of staff from the Faculty of Education and the Faculty of Social Work of the University of Ljubljana drafted a theoretical background for strategies for identifying and assessing general LD and SpLD, providing assistance and support, and team-based solution finding. Inclusion teams (the project Using Inclusion Teams to Implement the Concept 'Learning Difficulties in Primary School' 2009-2011) helped to test the findings in practice. Four books were published and distributed to all primary and secondary schools free of charge with the following topics: Pupils with Learning Difficulties - Selected Topics; Identification and Diagnostic Assessment; Assistance and Support; Individual Working Project of Help. All of the materials on learning difficulties and SpLD produced as part of the project are still available to interested parents and education professionals on the website www.ucne-tezave.si.

This outline of the Context of Influence indicates that good planning and systematic activities can create the conditions for the development of an inclusive treatment policy for children on the continuum of general LD and the continuum of specific LD.

\section{The Context of Policy Text Production}

The Context of Policy Text Production is concerned with the drafting of laws and other documents, in this case those that enable the enactment of SEN policy. According to Ball (1994), legal documents are necessarily a product of compromise at various levels of policy-making, from the early conceptual influence of interested parties, to the reading and adoption processes in parliament. E. Tikondwe Kamchedzera (2011) notes that the production of policy text in the field of SEN depends on the motivation of the elites for inclusion implementation, 
on the perception of inclusion and special needs concepts, and on the choice of paradigms that influence the policy and the rights of people with SEN.

Internationally, inclusive education is seen as a reform that supports diversity amongst all children, and as a principle that defines education as a basic human right and the foundation for a more just and equal society (Ainscow \& Sandill, 2010). The following international documents are some of the key policy texts comprising the legal framework that supports inclusion: The Universal Declaration of Human Rights (1948); The UN Convention on the Rights of the Child (1989); The World Declaration on Education for All (1990); The Standard Rules on the Equalization of Opportunities for Persons with Disabilities (1993); The Salamanca Declaration (1994); The Right to Education for Persons with Disabilities: Towards Inclusion (2001); The Convention on the Rights of Persons with Disabilities (2006), etc. (in UNESCO, 2005; UNESCO, 2009).

Vital for the development of the field of SpLD is the Written Declaration 64/2007 on "dys"crimination and social exclusion affecting children with "dys"abilities, adopted in the EU Parliament on 12 November 2007 (RejouisPanayotopoulos, 2007). The declaration was signed by the majority of Slovenia's MEPs.

As the SEN of children with SpLD range on a continuum from less to more explicit, legislation in Slovenia governs the rights of children with SpLD with two acts: the Elementary School Act (1996), and the Placement of Children with Special Needs Act (ZUOPP, 200o). Children with mild and moderate SpLD are entitled to the same forms of support as children with general LD, and their rights are defined in the Elementary School Act (1996, Article 11, Paragraph 2). These include the right to remedial education, adaptation of working methods and approaches, and individual and group support. With the amended Elementary School Act of 2011, however, children with mild and moderate SpLD were denied the status of SEN, but retained the right to educational assistance, adaptation of working methods and approaches, and individual and group support (Article 12a of Elementary School Act, 2011).

In enacting the right of children with severe SpLD to major adaptations in their education process and more specific forms of additional professional assistance, the proposer of ZUOPP was compelled to yield to pressure from professionals and parents and make compromises. The inclusion of children with severe SpLD in ZUOPP (200o) allows for additional rights to more effective treatment of these children (Vršnik Perše, 2009). A team of experts (S. Tancig, L. Magajna, \& M. Kavkler, in Vršnik Perše, 2009) drafted an amendment that specifies the need to include children with severe SpLD in ZUOPP (Article 2 of ZUOPP, 200o). MP Ana Kragelj-Zbačnik submitted the amendment for a 
decision procedure on the inclusion of children with severe SpLD in ZUOPP (2000). During the second reading of ZUOPP (2000) to discuss the amendment on the inclusion of children with severe SpLD in Article 2 of ZUOPP (2000), the proposer justified their disagreement with the proposed amendment by noting that children with severe SpLD had already been categorised as children with a long-term illness, fearing the placement of the entire $20 \%$ of children with low achievement rather than just $2-4 \%$ of children with severe SpLD (Poročevalec 2000, No. 71, p. 11, Paragraph 2). The reasoned opinion on the importance of the specific treatment of children with severe SpLD submitted by professionals from the Counselling Centre for Children, Adolescents and Parents Ljubljana was instrumental in the ZUOPP (2000) proposer's decision to include children with severe SpLD in ZUOPP (2000) as SEN. However, in the subsequent version of the draft ZUOPP (2000, Article 2), the proposer referred to children with SpLD as children with developmental and neurological disorders. Ravnik (200o) and the Child Neurology Department of the Slovenian Medical Association (2000) opposed this term and the inclusion of a neurologist in the assessment of severe SpLD, emphasising that the assessment and treatment of severe SpLD is primarily an educational issue, even if the causes of the disability are neuro-physiological. In the second reading, the proposer decided to include children with severe SpLD in ZUOPP (2000) as a separate category; however, prior to the adoption of the act in the National Assembly of the Republic of Slovenia, a team of experts (M. Kavkler, L. Magajna, L. Marjanovič Umek, Čuk, \& Opara, in Vršnik Perše, 2009) had to formulate a term that would clearly delineate severe SpLD from LD. Thus, the term deficits in individual learning areas was formulated to denote severe SpLD. By including them as SEN in ZUOPP (200o), children with severe SpLD gained the right to adaptations in their education process and testing, and to additional professional assistance (1-5 hours).

Two laws have been adopted within the context of policy text production that allow for the implementation of the continuum of rights of children with SpLD. Children with severe SpLD were included in ZUOPP (2000) following pressure from professionals and parents of children with SpLD. One of the decisive factors behind the adoption of the amendment to ZUOPP (2000) was the support of 80 influential professionals from the fields of medicine, education and social services. Later, the amendment also gained support from members of the Slovenian Special Education Association and representatives of parliamentary groups. A number of compromises were required in all stages of adopting ZUOPP (2000), from conceptual influence by interested parties, to the reading and adoption processes in the National Assembly. 


\section{The Context of Practice}

The context of practice concerns the reinterpretation and implementation of inclusive policy in education practice. In schools, those entrusted with the implementation of the legislated inclusive policy in practice include teachers, principals and other education professionals, but rarely pupils and parents. Education professionals interpret the policy in accordance with their own views, perceptions, experience, history, aspirations, values, knowledge, intentions, meanings and the preferred approaches. These factors, and many more, have an influence on how successfully inclusion is implemented in practice.

Despite being recognised as effective in the EU and many other countries, and despite being corroborated by a number of studies and international declarations, inclusive practice is still a major challenge for many teachers and other education professionals in Slovenia when it comes to its implementation in practice (Kavkler, 2011). Indeed, as Zgaga (Žolnir, 2010) emphasised at the Standing Conference of European Ministers of Education of the Council of Europe, teachers should gain the competence to teach their subject, as well as the ability to do so with a varied population of children in the classroom.

The Written Declaration 64/2007 on "dys"crimination and social exclusion affecting children with "dys"abilities emphasised the importance of promoting good practice, access to information, systematic and early diagnostics, lifelong assistance and support, and treatment of persons with SpLD by designing effective pedagogical approaches that improve standard and special pedagogical assistance and support for children and adults with SpLD (Rejouis-Panayotopoulos, 2007).

In Slovenia, the development of inclusive practice for all children, especially those with SpLD, has been too slow, with education policy and efforts in practice more focused on knowledge standards and the results of national and international testing rather than on children's needs. The attention of the media is attracted by individuals who stand out for their talents despite their SpLD. More often than their peers without SpLD, children with SpLD are frustrated with their underachievement and are poorly integrated into their social environment. Those who lack adequately adapted demands from the early stages of their education process, and who are given no effective professional assistance, struggle with the successful continuation of their education process and with integration into society. Above all, the quality of inclusive practice in the classroom, manifested as various inclusive or non-inclusive teaching methods that have a vital impact on the performance of children with SpLD, depends on teachers' perceptions, knowledge and teaching strategies (Vidovich, 2001; 
Kavkler, 2011). In the teaching and testing processes, the school's education professionals often merely reduce the complexity and abstractness of assignments instead of enabling children specific adaptations in reading, writing, arithmetic and spelling (e.g., adjustments in study materials, the use of study and technical aids, longer times, etc.), as required by their SEN. Problems with adequate adjustment of demands are related to the perceptions, readiness and competence of education professionals to use the five-step RTI approach. Any child who fails to meet education targets should have his/her education process adapted by the teacher, and should be given assistance by a school counsellor, as well as individual or group study support. When it comes to selecting professionals for intensive and specific forms of assistance, the focus is all too often on the opportunity to increase staff rather than on providing effective assistance for a child with SpLD. Many of those who practice additional assistance have not been adequately trained, or lack the required knowledge and strategies to effectively diagnose and provide assistance and support to children with severe SpLD, who need the most intensive and most specific forms of assistance. Unfortunately, unlike the performance of children with severe SpLD, the effectiveness of either implementing adaptations in the teaching process or providing additional assistance is never subject to evaluation.

Children with SpLD can achieve their fullest potential if they have access to high-quality instruction based on research findings, taking account of the SEN of the individual and including ongoing monitoring and evaluation of the child's progress, which enables education professionals to adequately adapt the teaching process and treatment of children with SpLD (NRCLD, 2007; RRCNA, 2010). There are a number of successful professionals in Slovenia who believe that inclusive education of children with SpLD is possible and rational, and who have the required knowledge for its implementation. This is the practice in schools with a clear policy towards inclusion and with a principal who supports his/her staff by giving them access to material and scientific resources and helping them acquire the knowledge and skills required to provide inclusive education to all children with SEN, including those with SpLD (European Commission/EACEA/Eurodyce, 2012).

As changing perceptions, learning new approaches and implementing team work are long-term processes, no change of school practice is quick or easy. Advice alone is not enough for teachers and other education professionals to change their teaching process and treatment of children with SpLD; the implementation of these tasks takes effort and time. Education professionals need positive perceptions, knowledge, experience and support, which is why "Inclusive Education" is part of students' curricula in education faculties in Slovenia, 
so that all future teachers can learn about the basics of the identification and treatment of children with general LD and SpLD. In addition, the Faculty of Education of the University of Ljubljana organises a one-year training programme on working with children and adolescents with SpLD and emotional and behavioural disorders for education professionals in schools. Many seminars are also organised by other institutions.

Another organisation committed to developing the full potential of children with SpLD is the Bravo Association for Helping Children and Adolescents with SpLD (www.drustvo-bravo.si), which focuses on raising public awareness about the typical features and SEN of persons with SpLD, producing publications and organising international conferences, seminars and other forms of training for persons with SpLD, their parents and education professionals.

As is clear from the context of practice, the implementation of changes towards inclusive educational practice for children with SpLD is slow. The enacted rights of children with SpLD are repeatedly disregarded. All too often, the effectiveness of assistance depends on the perceptions and knowledge of the education professionals who teach the children in the classroom or provide them with study support and additional assistance. On the other hand, there are education professionals with positive perceptions and knowledge who are ready to work with all of the participants in the education process in order to create the conditions for children with SpLD to achieve the best possible results.

\section{Conclusions}

In Slovenia, the development of inclusive practice has been too slow. Legal grounds for its implementation are provided, but the gap between legislation and practice remains all too wide. While focusing on SpLD, the present article has attempted to analyse different factors that hinder the development of inclusive practice. With Ball's model (1994), we were able to analyse the situation from the contexts of policy influence, text production and practice. Within the context of inclusive policy influence, we presented the key elements of forming the conceptual framework for the treatment of children with SpLD, together with part of the materials enabling the conditions for the implementation of inclusive policy in practice. Within the context of policy text production, we explained how professionals influenced the drafting of the law that enabled children with severe SpLD to acquire the status of children with SEN, and thus gain more rights to adapted education and to additional professional assistance. Policy and legislation offer the conditions for the implementation of inclusive education of children with SpLD. In practice, however, children 
with SpLD are often discriminated against, and their learning achievements are generally much lower than the achievements of their peers without SpLD. By implementing the five-tier RTI approach, which includes appropriate adaptations and effective forms of both learning and additional professional assistance, many children with SpLD could attain significantly better learning achievements and social inclusion.

No change in the area of educating children with SpLD can be achieved quickly. Positive changes can be expected with future teachers, who now acquire at least basic knowledge about SpLD during their studies. Moreover, positive changes can be expected due to the many school education professionals who already share a positive attitude towards children with SpLD, who know how to find solutions in collaboration with other participants, and who possess the knowledge and strategies for effective teaching and for offering various forms of both learning and additional professional assistance. Education professionals should stop focusing only on deficits and shift to the prospects of the ability, identification and utilisation of the individual's strengths, encouraging the factors that can lead to a successful life and career even when some SpLD remain.

\section{References}

Ainscow, M. (2003). Developing inclusive education system: what are the levers for change? International conference on inclusive education. Hong Kong, 16.-19. 122003.

Ainscow, M. (2005). From special education to effective school for all. Inclusion celebrating diversity. Inclusive and Supportive Education Congress. Glasgow, 1.-4. August 2005.

Ainscow, M., \& Sandill, A. (2010). Developing inclusive education system: the role of organisational cultures and leadership. International Journal of Inclusive Education, 14(4), 401-416.

American Psychiatric Association. (2013). Diagnostic and Statistical Manual of Mental Disorders

(Fifth ed.). Arlington, VA: American Psychiatric Publishing.

Ball, S. J. (1994). Education reform: A critical and post-structural approach. Buckingham: Open University Press.

Bassanini, A., \& Scarpetta, S. (2001). The driving forces of economic growth: Panes data evidence from OECD countries. OECD Economic Studies, 33, 9-53.

Drabble, S. (2013). Support for children with special educational needs (SEN). Brussels: European Commission, Directorate-General for Employment, Social Affairs and Inclusion.

European Agency for Development in Special Education. (2010). Teacher Education for inclusion

- International Literature Review. Odense, Denmark: Author. Retrieved 21 May 2011, from www. european.agency.org

European Commission/EACEA/Eurydice. (2012). Developing Key Competences at School in Europe: 
Challenges and Opportunities for Policy. Eurydice Report. Luxembourg: Publications Office of the European Union.

European Agency for Development in Special Needs Education. (2009). Key Principles for Promoting Quality in Inclusive Education - Recommendations for Policy Makers. Odense, Denmark: Author. Falvey, M. A., \& Givner, C. C. (2005). What is an inclusive school? In R. A. Villa \& J. S. Thousand (Eds.), Creating an inclusive school (pp. 1-26). Alexandria, VA: Association for Supervision and Curriculum Development.

Hargrass, H. (2005). Definitions of disability and disability policy in Egypt. In C. Barnes \& G.

Mercer (Eds.), The Social Model of Disability: Europe and the Major World (pp. 148-162). Leeds: The Disability Press.

Hegarty, S. (2003). Inclusion and EFA: Some perspectives from outside education. International conference on inclusive education. Hong Kong, 16.-19.12. 2003, pp. 23-32.

ICD-10 - International classification of diseases and related health problems, 1oth revision. (1992).

Geneva: World Health Organization.

Jereb, A. (2011). Ekonomske posledice učne neuspešnosti. In S. Pulec Lah \& M. Velikonja (Eds.), Učenci z učnimi težavami v osnovni šoli: izbrane teme (pp. 52-66). Ljubljana: UL, Pedagoška fakulteta. Kavkler, M. (2011). Konceptualne osnove obravnave učencev z učnimi težavami. In M. Košak Babuder \& M. Velikonja (Eds.), Učenci z učnimi težavami v osnovni šoli: pomoč in podpora (pp. 842). Ljubljana: UL, Pedagoška fakulteta.

Kavkler, M., Bregar-Golobič, K., Čačinovič Vogrinčič, G., Magajna, L., Klug, M., Pečjak, S., \& Vernik, H. (2008). Otroci s primanjkljaji na posameznih področjih učenja: navodila za prilagojeno izvajanje programa osnovne šole z dodatno strokovno pomočjo. Ljubljana: Zavod RS za šolstvo.

Kavkler, M., \& Magajna, L. (20o8). Opredeltiev, razsežnost, podskupine učnih težav. In L. Magajna, S. Pečjak, C. Peklaj, G. Čačinovič Vogrinčič, K. Bregar Golobič, M. Kavkler, \& S. Tancig, Učne težave v osnovni šoli - problemi, perspektive, priporočila (pp. 23-32). Ljubljana: Zavod RS za šolstvo.

KOP (Konvencija OZN o pravicah otrok, 1990). Ljubljana: UNICEF.

Lerner, J. (2003). Learning Disabilities: Theories, Diagnosis and Teaching Strategies. Boston, MA: Houghton Mifflin Company.

Lorenz, S. (1999). Making inclusion work for children with Down syndrome. Down Syndrome News and Update, 1(4), 175-180.

Magajna, L., \& Kavkler, M. (2002). Primanjkljaji na posameznih področjih učenja (PPPU). In M. Kavkler (Ed.), Razvijanje potencialov otrok in mladostnikov s specifičnimi učnimi težavami zbornik prispevkov. Kranjska Gora, 26.-28.9.2002 (pp. 3-6). Ljubljana: Svetovalni center za otroke, mladostnike in starše Ljubljana, Društvo Bravo; Different, d.o.o.

Magajna, L., Kavkler, M., \& Križaj Ortar, M. (2003). Adults with Self-Reported Learning Disabilities in Slovenia: Findings from the International Adult Literacy Survey on the Incidence and Correlates of Learning Disabilities in Slovenia. Dyslexia, 9(4), 229-251.

Magajna, L., Pečjak, S., Peklaj, C., Bregar-Golobič, K., Čačinovič Vogrinčič, G., Kavkler, M., \& Tancig, S. (2005). Učne težave v osnovni šoli - razvoj celovitega sistema učinkovite pomoči : raziskovalno 
poročilo. Ljubljana: Razvojno-raziskovalni inštitut Svetovalnega centra.

Magajna, L., Kavkler, M., Čačinovič Vogrinčič, G., Pečjak, S., Bregar-Golobič, K., \& Nagode, A. (Ed.)

(2008a). Učne težave v osnovni šoli: koncept dela, (Program osnovnošolskega izobraževanja). 1. natis.

Ljubljana: Zavod RS za šolstvo.

Magajna, L., Pečjak, S., Peklaj, C., Čačinovič Vogrinčič, G., Bregar-Golobič, K., Kavkler, M., \&

Tancig, S. (2008b). Učne težave v osnovni šoli-problemi, perspektive, priporočila. Ljubljana: Zavod RS za šolstvo.

Magajna, L., Kavkler, M., Košak Babuder, M., Zupančič Danko, A., Seršen Fras, A., \& Rošer, A.

(2014). Otroci s primanjkljaji na posameznih področjih učenja. VII. In N. Vovk Ornik (Ed.), Kriteriji za opredelitev vrste in stopnje primanjkljajev, ovir oz. motenj otrok s posebnimi potrebami (pp. 23-31).

Ljubljana: Zavod RS za šolstvo.

Meijer, C., Soriano, V., \& Watkins, A. (Eds.) (2003). Special needs education in Europe. Thematic

Publication. Middlefart, Denmark: European Agency for Development in Special Needs Education.

National Research Centre on Learning Disabilities NRCLD. (2007). Core concepts of RTI. Retrieved

26 January 2009, from http://www.ncrld.org/about/research/rti/concepts.html

Oliver, M. (2004). The social model of disability in action: if I had a hammer. In C. Barnes \& G.

Mercer (Eds.), Implementing the Social Model of Disability: Theory and Research (pp. 18-31). Leeds:

The Disability Press.

Peček Čuk, M., \& Lesar, I. (2010). Učitelji o vedenjskih reakcijah in učnem uspehu učencev s posebnimi potrebami v redni osnovni šoli. In A. Kobal (Ed.), Izstopajoče vedenje in pedagoški odzivi (pp. 165-208). Ljubljana: UL Pedagoška fakulteta.

Poročevalec DZ, no. 71/200o.

Ravnik, M. I. (2000). Dopis državni sekretarki Ministrstva za zdravstvo SRS Dunji Kosmač Piškur.

Ljubljana: Sekcija za otroško nevrologijo.

Reading Recovery Council of North America RRCNA. (2010). Response to intervention in grade one: Reading recovery. Summary report. Retrieved 15 August 2012, from http://www.nrcld.org/about/ research/rti/concelts.html

Rejouis-Panayotopoulos, M. (2007). Opening Adress at EDA Conference. EDA NEWS, 1(5), 21-28. Republiški izpitni center (RIC). (2013). Splošne informacije o NPZ. Retrieved 12 November 2013, from www.ric.si/preverjanje_znanja/splosne_informacije

Sekcija za otroško nevrologijo SZD. (200o). Poročilo Upravnega odbora sekcije za otroško nevrologijo.

Ljubljana: SPS Pediatrična klinika.

Srebotnik, I. (2013). Spodbudno in zelo sporočilno. Šolsko razgledi, LXIV (7, 12. April).

SURS (2012). Osnovnošolsko izobraževanje mladine in odraslih v Sloveniji ob koncu šolskega leta 2010/2011. Retrieved 16 September 2013, from http://www.stat.si/novica_prikazi.aspx?id=4636 Štraus, M., Šterman Ivančič, K., \& Štigl, S. (2013). OECD PISA 2012 : matematični, bralni in naravoslovni dosežki slovenskih učencev: program mednarodne primerjave dosežkov učencev 2012 : nacionalno poročilo. Ljubljana: Pedagoški inštitut.

Tikondwe Kamchedzera, E. (2011). Education of pupils with disabilities in Malawi's inclusive secondary 
schools: policy, practice and experiences. Doctoral thesis. Warwick: University of Warwick, Institute of education.

UNESCO. (2001). Open file on inclusive education: the rationale for inclusive education. Support Materials for Managers and Administrators. Paris, UNESCO.

UNESCO. (2005). Guidelines for Inclusion: Ensuring Access to Education for ALL. Paris: United Nations Educational, Scientific and Cultural Organization.

UNESCO. (2009). Inclusive and Child Friendly Education. Retrieved 10 October 2010, from http:// unesco.org.pk/education/icfe/

UNICEF. (2007). Promoting the rights of children with disabilities. Innocenti Digest, (13). Florence: Innocenti Research Centre.

Vidovich, L. (2001). A conceptual framework for analysis of education policy and practices: paper proposed for presentation at the Australian Association for Research in Education. Fremantle,

December 2001.

Vršnik Perše, T. (2009). Izobraževanje otrok s posebnimi potrebami. Znanstvena poročila Pedagoškega instituta 05/2009. Ljubljana: Pedagoški institut.

Zakon o osnovni šoli (1996). Uradni list Republike Slovenije, Nu. 12, 29. 11. 1996.

Zakon o osnovni šoli (2011). Uradni list Republike Slovenije, Nu. 87/11, 2. 11. 2011.

Zakon o usmerjanju otrok s posebnimi potrebami (ZUOPP) (200o). Uradni list Republike Slovenije, Nu. 54/2000.

Zakon o usmerjanju otrok s posebnimi potrebami (ZUOPP-1) (2011). Uradni list Republike Slovenije, Nu. 58/2011.

Žolnir, N. (2010). Časi elitizma v šolstvu so minili. Delo, 7. 6. 2010, Year 52, No. 129, p. 4.

\section{Biographical note}

Marija Kavkler, $\mathrm{PhD}$, is an Associate Professor of special and rehabilitation education at the Faculty of Education, University of Ljubljana. Her knowledge and experience is transferred to undergraduate and postgraduate students and academic professionals in various forms of training. Her field of research is related to inclusive education for children and adolescents with special needs, especially those with general and specific learning difficulties. She was involved in a number of national and international projects dealing with school underachievement of children and adolescents. She has participated in the preparation of key documents in the field of special education in Slovenia. By combining theoretical knowledge and practical experience she strives for inclusive education which will largely take into account the needs of a diverse population of children and adolescents. 
Milena Košak BABUder, PhD, is an Assistant in the Department of Special education at the Faculty of Education, University of Ljubljana. Her fields of research are the exploration of the effects of poverty and general and specific learning difficulties on educational performance of primary and secondary school students and development of strategies and models of support and treatments in these areas. She also runs many workshops and seminars on specific learning difficulties for in-service teachers and school counsellors.

Lidija Magajna, PhD, received her doctorate in psychology from the Faculty of Arts, University of Ljubljana. She is currently working as an assistant professor of psychology in education at the Department of Special and Rehabilitation Education at the Faculty of Education, University of Ljubljana and as head of the research unit at the Counselling Centre for Children, Adolescents and Parents in Ljubljana and has extensive clinical experience in assessment, counselling and prevention of learning and psychosocial problems. Her research interests include cognitive, developmental and neuropsychological aspects of learning disabilities, school underachievement and related psychosocial problems and comparative studies of early reading and arithmetic development. 